\title{
Rebon Shrimp Powder Addition Influence to Nutritional Values, Organoleptic Properties and Acceptance of Supplementary Food by Children Aged 4-5 Years Old
}

\author{
Pengaruh Penambahan Bubuk Udang Rebon terhadap Nilai Gizi, Sifat \\ Organoleptik, dan Daya Terima Makanan Tambahan Anak Usia 4-5 Tahun
}

Priyo Sulistiyono*, Dewi Marhaeni Diah Herawati**, Insi Farisa Desy Arya***

*Diploma in Nutrition Program of Cirebon, Tasikmalaya Health Polytechnic Ministry of Health, Tasikmalaya, Indonesia, **Faculty of Medicine, University of Padjadjaran, Bandung, Indonesia

\begin{abstract}
Malnutrition and stunting prevalence in under-five children in Cirebon City are still high that reach $13.9 \%$ and $15.7 \%$. Rebon shrimp (Acetes erythraeus) contains high protein and calcium. Influence of adding rebon shrimp in supplementary food (lemu porridge and steamed sponge) towards nutrition quality was investigated. This study aimed to determine effects of rebon shrimp powder on nutritional values, organoleptic properties and food acceptance. Laboratory test and Nutriservey software were used to measure nutritional value of rebon shrimp powder and nutrition of supplementary food. Organoleptic test used completely randomized design with four treatments (0\%,5\%,10\%, $15 \%$ shrimp powder) and two repetitions. Respondents were 30 students of Nutrition Studies Program in Cirebon with 7 hedonic scale (organoleptic test) and 50 children aged 4-5 years in integrated health care (acceptance test). As the result, the level of ash, protein and calcium of rebon shrimp powder met the Indonesian National Standard. Energy, protein and calcium significantly increased ( $p$ value < 0.05).Nutrient content of steamed sponge per 100 gram with $5 \%$ rebon shrimp powder supplied $21.6 \%$ energy, $18.9 \%$ protein and $25.9 \%$ calcium on recommended dietary allowances. Preference level of color, flavor, taste, texture and overall were significantly different. Lemu porridge with $5 \%$ rebon shrimp powder was accepted by $80 \%$ of the children and the steamed sponge acceptance reached $88 \%$.
\end{abstract}

Keywords: Children, malnutrition, rebon shrimp powder, supplementary food

\begin{abstract}
Abstrak
Prevalensi gizi kurang dan stunting pada anak bawah lima tahun (balita) di Kota Cirebon masih cukup tinggi yaitu mencapai 13,9\% dan 15,7\%. Udang rebon (Acetes erythraeus) memiliki kandungan protein dan kalsium yang tinggi. Pengaruh penambahan udang rebon dalam makanan tambahan (bubur lemu dan bolu kukus) terhadap kualitas gizi diteliti. Penelitian ini bertujuan untuk mengetahui pengaruh bubuk udang rebon terhadap nilai gizi, sifat organoleptik dan daya terima. Uji laboratorium dan perangkat lunak Nutriservey digunakan untuk analisis nilai gizi bubuk udang rebon dan gizi makanan tambahan. Uji organoleptik menggunakan rancangan acak lengkap dengan empat perlakuan (bubuk udang rebon 0\%, 5\%, 10\%, 15\%) dilakukan dua kali pengulangan. Responden adalah 30 mahasiswa program studi gizi Cirebon, mrnggunakan 7 skala hedonik (uji organoleptik) dan 50 anak-anak usia 4-5 tahun di posyandu (uji daya terima). Hasilnya adalah kadar abu, protein dan kalsium bubuk udang rebon memenuhi Standar Nasional Indonesia. Energi, protein dan kalsium meningkat signifikan (nilai $p<0,05$ ). Kandungan gizi per 100 gram bolu kukus dengan bubuk udang rebon $5 \%$ memenuhi angka kecukupan gizi energi $21,6 \%$, protein $18,9 \%$ dan kalsium $25,9 \%$. Tingkat kesukaan pada warna, aroma, rasa, tekstur dan keseluruhan berbeda signifikan (nilai $p<0,05$ ). Bubur lemu dengan bubuk udang rebon $5 \%$ dapat diterima oleh $80 \%$ balita dan bolu kukus mencapai $88 \%$.

Kata kunci: Anak-anak, gizi kurang, bubuk udang rebon, makanan tambahan

How to Cite: Sulistiyono P, Herawati DMD, Arya IFD. Rebon shrimp powder addition influence to nutritional values, organoleptic properties and menu acceptance in supplementary food of children ages 4-5 years old. Kesmas: National Public Health Journal. 2017; 11 (4): 168-172. (doi:10.21109/kesmas.v11i4.1280)

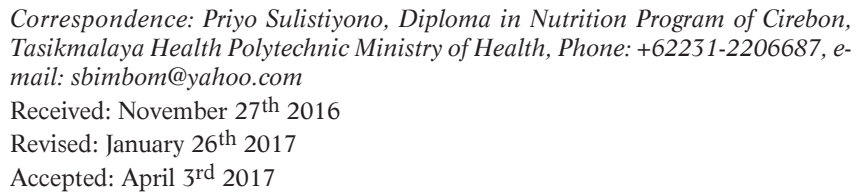

Copyright @ 2017, Kesmas: National Public Health Journal, p-ISSN: 1907-7505, e-ISSN: 2460-0601, Accreditation Number: 56/DIKTI/Kep/2012, http://journal.fkm.ui.ac.id/kesmas 


\section{Introduction}

Proportion of underweight and stunting in Indonesia increased in 2007-2013. Stunting increased from 18.4\% to $19.6 \%$ and the underweight increased from $36.8 \%$ to $37.2 \% .{ }^{1}$ Non-balanced diet was one of the problems. ${ }^{2,3}$ Supplementary food at integrated health care is one of nutrition improvement programs in Indonesia for underfive. They give to malnourished children for 90 consecutive days. Integrated health care gave the supplementary food every time they came to provide balanced nutrition samples. Quality of supplementary food in integrated health care, especially protein content, is still inadequate. Lemu porridge and steamed sponge are some of the local food included as supplementary food at integrated health care in Cirebon, West Java. They are made from flour with minimal protein content.

Shrimp contains high protein and calcium that are needed for growth process. Besides, shrimp also contains bioactive compounds, including chitosan and chitin. ${ }^{4}$ The results show that chitosan and chitin are beneficial for the body. They will suppress cell aging, prevent circulatory disease, strengthen immune system, increase the secretion of cholesterol in the body, suppress cancer cell proliferation and reduce overweightness. ${ }^{5-7}$

Previous studies of food products, including shrimp powder have been investigated before as shrimp sauce, teriyaki sauce, and cake with shrimp powder. $8-10$ However, there is no study finding that adding rebon shrimp powder for consumption of children aged 4-5 years has benefit to improve its nutritional value.

\section{Method}

This study included the making of rebon shrimp powder, formulation, analysis of the nutritional values, tes o the organoleptic properties, and acceptance by children aged 4-5 years. The organoleptic properties were tested using a completely randomized design with four treatments and two repetitions.

Cirebon's local variety of shrimp (Acetes erythraeus) known as rebon was used to make the powder. Procedure included washing, boiling, draining, drying at a temperature of $60^{\circ} \mathrm{C}$ (45 minutes), milling, and sieving $(60$ meshes). Water was added when boiling with jackfruit leaves and Indonesian bay leaves (Syzygium polyanthum) to reduce the fishy odor and allergen substances. Steamed sponge cupcakes and lemu porridge were the examples of supplementary food for children which has low nutritional value especially protein. Therefore, the study tried to add rebon shrimp powder into those meals.

To make the steamed sponge cupcake, eggs and sugar were mixed for 7 minutes, then flour, rebon shrimp powder, and water was added and stirred again for 7 minutes. The batter was poured into the mold and then steamed for 15-20 minutes. For lemu porridge, rice flour was dis- solved in coconut milk and mixed well. After that, rebon shrimp powder was added with salt, screwpine leaf, and flavor additives (if necessary), then it was simmered over low heat while stirring until the porridge was thick and cooked. Brown sugar, granulated sugar and water was mixed and boiled until the sugar dissolved to make sugar sauce. Cornstarch solution was added little by little while stirring constantly. Also, coconut milk sauce was made by mixing coconut milk with salt and then boiling the mixture while stirring. Lemu porridge was ready to serve in a bowl. Sugar sauce and coconut milk were poured into the porridge.

In Table 1, rebon shrimp powder with concentration of $5 \%, 10 \%$, and $15 \%$ was given to the group that received procedure, could not given to the control group. Sensory or organoleptic test in this study used the hedonic scale (food preference) with a scale of seven levels from $1=$ strongly not preferred to $7=$ strongly preferred. ${ }^{11}$ The test was done by 30 nutrition diploma students in Cirebon. Analysis of the nutritional values of $r e$ bon shrimp powder was conducted at the Laboratory of Chemistry, Padjadjaran University, Bandung. The study used a regular oven, dry ashing method, mikrokjeldahl, and Atomic Absorption Spectrophotometre, respectively for water, ash, protein, and calcium contents. Analysis of the nutritional value of the menu used the composite method with Nutrisurvey software (food composition table of Indonesian). ${ }^{12}$ Acceptance testing for supplementary food with rebon shrimp powder $(5 \%)$ was performed by one-group post-test. The total of respondents was 50 children aged 4-5 years old who had no records of allergy to shrimp. This study took place at Anggrek Posyandu (Integrated Health Service Post) in Harjamukti Subdistrict, Cirebon City. Acceptance was measured by Comstock Visual Rating using a scale of 1-5, i.e., $1=$ eaten all (devoured) $(0 \%)$ to $5=$ not eaten at all $(100 \%)$.

Table 1. Ingredient Composition of Supplementary Food with Rebon Shrimp Powder

\begin{tabular}{lrrrr}
\hline & \multicolumn{3}{c}{ Concentration of Rebon Shrimp Powder } \\
\cline { 2 - 5 } Menu & Control (0\%) & $\mathbf{5 \%}$ & $\mathbf{1 0} \%$ & $\mathbf{1 5 \%}$ \\
& & & & \\
\hline Steamed sponge cake: & 100 & 100 & 100 & 100 \\
Wheat flour (gram) & 10 & 10 & 10 & 10 \\
Sugar (gram) & $1 / 2$ & $1 / 2$ & $1 / 2$ & $1 / 2$ \\
Egg whites & 1 & 1 & 1 & 1 \\
Baking powder (gram) & $1 / 4$ & $1 / 4$ & $1 / 4$ & $1 / 4$ \\
Vanilla essence (tea spoon) & 0 & 5 & 10 & 15 \\
Rebon shrimp powder (gram) & & & & \\
\hline Lemu porridge: & 10 & 100 & 100 & 100 \\
Rice flour (gram) & 5 & 5 & 10 & 10 \\
Sugar (gram) & 2 & 5 & 5 \\
Coconut milk (gram) & 0 & 5 & 10 & 15 \\
Salt (gram) & & 2 & 2 \\
Rebon shrimp powder (gram) & & & & \\
\hline
\end{tabular}


Data on the nutrient content (water, ash, protein and calcium) of the rebon shrimp powder compared to the Indonesian National Standard for flour, seasonings, spices and fish nutritional values of the rebon shrimp powder compared to the Recommended Dietary Allowance (RDA). ${ }^{13}$ Organoleptic test data was analyzed by One-way ANOVA and Post Hoc (LSD). Binomial statistical test used to determine whether the power of acceptance exceeded $75 \%$.

\section{Results}

Rebon shrimp powder has potential nutritional values, especially protein and calcium. Besides, rebon shrimp powder has low water content as this material can be kept for longer period of time. In the Table 2, water content of the rebon shrimp powder reached $3.42 \%$, ash content $13.31 \%$, protein content $73.59 \%$, and calcium content $69.45 \%$.

Results of nutrient content calculation with Nutrisurvey software showed that energy content, protein and calcium food additives increase along with increasing percentage additions of rebon shrimp powder. Energy content increased for $5 \mathrm{kcal}$, protein 1.2 gram, and calcium $46.1 \mathrm{mg}$ per 100 gram supplementary food. In the Table 3, highest energy, protein, and calcium content of the rebon shrimp powder found in lemu porridge and steamed sponge cake with $15 \%$ concentration of rebon shrimp powder.

Table 4 presents level preference of these meals. Score 1 is for dislike very much and score 7 for like very much. Overall preference level for color, taste, flavor, and texture of these meals in supplementary food was the highest in control group $(5.70 \pm 1.10)$. Adding $5 \%$ rebon powder into supplementary food had an average value of $5.22 \pm 1.04$ and significantly different ( $p$ value $<0.05$ ) Mean percentage contentment in respondents decreased along with the addition of rebon shrimp powder in steamed sponge cupcake and lemu porridge.

Acceptance test results on lemu porridge and steamed sponge cakes with the addition of 5\% rebon shrimp powder by children aged $4-5$ years old found that $68 \%$ children devoured lemu porridge and $72 \%$ eat up steamed sponge cupcake. Only $12-16 \%$ of food remain leftover for more than $75 \%$, so $84 \%$ of children were able to accept lemu porridge with the addition of $5 \%$ rebon shrimp powder and $88 \%$ for steamed sponge cake. In addition, the binomial test results with test-proportion 0.75 (onetailed) on a single sample in 50 under-five children showed $\mathrm{p}$ value $<0.005$.

\section{Discussion}

Water content of the rebon shrimp powder reached $3.42 \%$. This figure was lower than the Indonesian standard requirements of wheat flour $(14.5 \%)$, seasoned
Table 2. Nutritional Composition of Rebon Shrimp Powder

\begin{tabular}{lc}
\hline Composition & Concentration $(\%)$ \\
\hline Water content & $3.42 \pm 0.04$ \\
Ash content & $13.31 \pm 0.03$ \\
Protein & $73.59 \pm 0.89$ \\
Calcium & $69.45 \pm 0.29$ \\
\hline
\end{tabular}

Table 3. The Nutritional Composition of Rebon Shrimp Powder per 100 gram*

\begin{tabular}{lcrrr}
\hline Menu/Nutrient content & Control (0\%) & $\mathbf{5 \%}$ & $\mathbf{1 0 \%}$ & $\mathbf{1 5 \%}$ \\
\hline Steamed sponge cake & & & & \\
$\quad$ Energy (kcal) & 264.0 & 271.0 & 277.2 & 283.3 \\
Protein (gram) & 5.5 & 6.7 & 7.9 & 9.1 \\
Calcium (mg) & 27.0 & 73.1 & 119.2 & 165.3 \\
Lemu Porridge & & & & \\
Energy (kcal) & 339.6 & 345.7 & 351.9 & 358.0 \\
Protein (gram) & 4.1 & 5.3 & 6.5 & 7.7 \\
Calcium (mg) & 257.7 & 303.8 & 349.9 & 396.0 \\
\hline
\end{tabular}

*Analyzed with software Nutrisurvey

Table 4. Level of Preference for Steamed Sponge Cupcake and Lemu Porridge with Rebon Shrimp Powder

\begin{tabular}{lllll}
\hline Parameter & Control (0\%) & $\mathbf{5 \%}$ & $\mathbf{1 0} \%$ & $\mathbf{1 5 \%}$ \\
\hline Color & $5.59 \pm 1.39$ & $5.52 \pm 1.08$ & $5.42 \pm 1.16$ & $5.26 \pm 1.21 *$ \\
Taste & $5.75 \pm 1.12$ & $4.99 \pm 1.31 *$ & $4.64 \pm 1.35^{*}$ & $4.08 \pm 1.37 *$ \\
Flavor & $5.61 \pm 1.15$ & $4.98 \pm 1.31^{*}$ & $4.43 \pm 1.54 *$ & $4.01 \pm 1.44 *$ \\
Texture & $5.24 \pm 1.41$ & $5.43 \pm 1.17$ & $5.03 \pm 1.19$ & $4.81 \pm 1.31 *$ \\
Overall & $5.70 \pm 1.10$ & $5.22 \pm 1.04 *$ & $4.73 \pm 1.16^{*}$ & $4.23 \pm 1.26 *$ \\
\hline
\end{tabular}

*The mean difference is significant at the 0.05 level

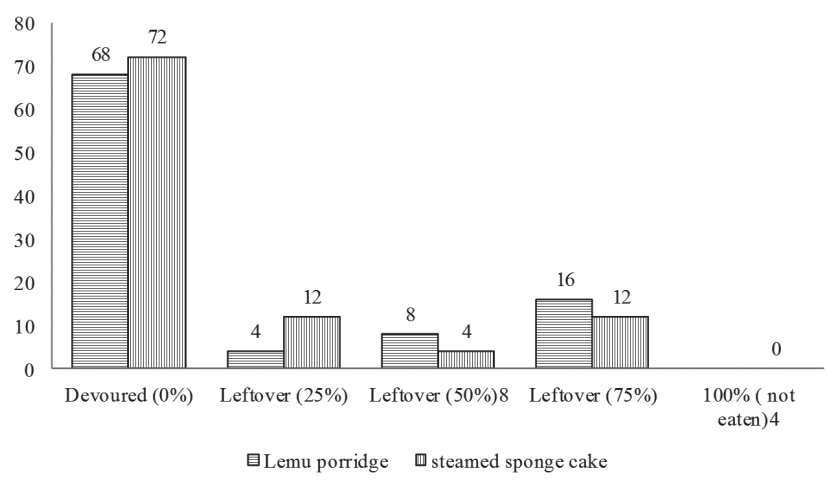

Figure 1. Power of Acceptance by Under-five on Lemu Porridge and Steamed Sponge Cupcake with 5\% Shrimp Powder

flour $(12 \%)$ and fish flour $(10 \%)$. It shows that the rebon shrimp powder has low water content (drier). Thus shelf life of rebon shrimp powder would be longer than other types of comparative flour.

Based on the Indonesian standard, the protein content of rebon shrimp powder $(73.59 \%)$ was higher than the fish flour (minimally 65\%) and seasoned flour (minimum $7 \%$ ). Powder also presented low ash content (minimally $20 \%)$.

Children need energy to grow, play, eat and do other activities in addition to fulfill their basal metabolic rate 
(BMR). Energy obtained from the burning of carbohydrates, fats and proteins in the body. Highest energy content of the rebon shrimp powder in this study reached $358 \mathrm{kcal}$, i.e., lemu porridge that reached $15 \%$ or $102.5 \%$ minimum standard of supplementary food energy of $350 \mathrm{kcal} .{ }^{13}$ Nutritional value of lemu porridge with $5 \%$ rebon shrimp powder was $21.6 \%$ RDA daily calories (1600 kcal per child per day). ${ }^{14}$

Protein is a nutrient that is essential for the body, as well as fuel that serves as builder and regulator substances. Protein is source of amino acids that contain the elements Carbon, Hydrogen, Oxygen, Nitrogen and it is unavailable in fats or carbohydrates. As builder substance, protein is material to form new tissues and this always happens in the body. During the process of growth, tissue formation occurs on a large scale. Therefore, in the future the protein intake must be sufficient to avoid impaired growth in the children.

Highest protein content of rebon shrimp powder was 9.1 gram in steamed sponge cupcake with $15 \%$ rebon shrimp powder. This protein reached $113.8 \%$ higher than protein in soya shrimp ball based on study by Fetty, 15 around $17.8 \%$. According to Desmelati, ${ }^{16}$ adding the rebon shrimp powder into nugget would increase protein content to $52.9 \%$. Minimum supplementary food standard of protein is 8 gram. Steamed sponge cupcake using $5 \%$ rebon shrimp powder could supply $18.9 \%$ protein adequacy for children aged 4-5 years old amounted to 35 gram per child per day. ${ }^{14}$

RDA of calcium for children 4-6 years old is $1000 \mathrm{mg}$ per child per day. ${ }^{14}$ Lemu porridge contained $5 \%$ rebon shrimp powder in this study met requirement, reaching $25.9 \%$. This content of the powder is lower than nugget rebon based on results of study by Desmelati, ${ }^{16}$ around $50.5 \%$. It was because of savory nugget, so more powder could be added on it.

Calcium function is essential for growth because calcium plays role helping in the formation of bones and teeth, regulating biological processes in the body. Calcium requirement is needed the most in childhood, especially for under-five and school-age children. Calcium in the blood circulation and tissue serves as transmission of nerve impulses, muscles contraction, blood clotting, setting of cell membrane permeability, and activity of the enzyme.

Porridge with 5\% rebon shrimp powder had the highest mean preference score $(5.22 \pm 1.08)$ compared to $10 \%$ and $20 \%$, but lower than meals without rebon shrimp powder (controls). Mean average level of preference for color of these meals was lowest at $15 \%$ rebon shrimp powder addition $(5.26 \pm 1.21)$ and highest at $0 \%$ of addition (5.59 \pm 1.39$)$. These results were above neutral score (4.0) but higher than results of study by Fatty, ${ }^{15}$ which added $15 \%$ rebon shrimp powder on tempeh shrimp ball, possibly reached 3.38 on acceptance score. Another study by Desmelati, ${ }^{16}$ showed that rebon shrimp powder addition could reach 4.12 on acceptance score.

Taste test on meals showed that the more rebon shrimp powder added the more dislike by children. Mean average level of preference for taste was lowest in 15\% addition $(4.08 \pm 1.37)$ and highest in control $(5.75 \pm 1.12)$. These results were above neutral score (4.0), but higher than results of study by Fatty, ${ }^{15}$ with acceptance score 2.96. Mean average level of preference for flavor was lowest at $15 \%$ addition $(4.01 \pm 1.44)$ and highest in control $(5.61 \pm 1.15)$. These results were above neutral score (4.0). This mean average was higher than study results by Fatty, ${ }^{15}$ (tempeh shrimp ball) with 3.39 for acceptance test and Desmelati, ${ }^{16}$ with 3.85 for acceptance test.

Mean average level of preference for texture was lowest at $15 \%$ addition $(4.81 \pm 1.31)$ and highest at $5 \%$ addition $(5.43 \pm 1.17)$. These results were above neutral score (4.0) and higher that Fatty's, ${ }^{15}$ results in tempeh shrimp ball with 3.23 on acceptance score and Desmelati, 16 in nugget with 3.84 of acceptance score. Another study by Djundjung, ${ }^{17}$ showed that given addition of rebon shrimp powder $2 \%$ in biscuit had similar acceptance score compared to commercial biscuit. Overall results showed that there was consistency of preference in each parameter. Generally, all menus could be accepted, but the addition of rebon shrimp powder tends to decrease the food acceptance.

Rebon shrimp powder addition on food additives has good preference level on organoleptic parameters, as well as the results of other studies, such as additions to the product sauce, appenzeller cheese, balls tempeh, cookies, instant noodles, biscuit and nugget.8,9,15-20

Results of the menu with 5\% rebon shrimp powder indicated that lemu porridge and steamed sponge were acceptable by $80 \%$ and $88 \%$ of children. These meals can be used as supplementary food for children aged 4-5 years old due to their acceptance that exceeded $75 \%$. In addition, the binomial test results with proportion test was 0.75 (one-tailed) on a single sample in 50 under-five children showed $\mathrm{p}$ value $<0.05$.

These results represented quite good acceptance rate compared to the test of other products such as tempeh balls, cookies, biscuits and instant noodles with acceptance ranging between 50-90\%.15,18-20 However, the acceptance obtained in this study was lower than shrimp nugget which reached $90 \%$ in result of study by Desmalati. ${ }^{16}$ This was due to the characteristics of the nugget which was savory in accordance with shrimp flavor.

\section{Conclusion}

Rebon shrimp powder has great potential to be used as supplementary food for children aged 4-5 years old. 
Recommendation for the shrimp powder addition is about $5 \%$. Feeding the children aged 4-5 years old should be little but often to get maximum protein and mineral intakes. Further long-term study should be conducted for children's acceptance consistency and to find out the impact on the nutritional values in the blood (albumin and calcium) and improved nutritional status.

\section{Acknowledgment}

The greatest gratitude to Dadang Kusnadi, and Dikdik Kurnia who have provided beneficial inputs for this study. We also thank to the Head of Development and Human Resources Board Ministry of Health, the Director of Tasikmalaya Health Polytechnic, and the Head of Nutrition Program of Cirebon.

\section{References}

1. Kementerian Kesehatan Republik Indonesia. Pokok-pokok hasil riset kesehatan dasar tahun 2013. Jakarta: Kementerian Kesehatan Republik Indonesia; 2013.

2. Kuntari T, Jamil NA, Kurniati O. Malnutrition risk factor for under five years. Kesmas: National Public Health Journal. 2013; 7 (12): 572-6.

3. Kusumawati E, Rahardjo S, Sari HP. Model of stunting risk factor control among children under three years. Kesmas: National Public Health Journal. 2015; 9 (3): 249-56.

4. Ryu BH. Antitumor immunologic activity of chitosan extacted from shell of shrimp. Journal Korean Food Sciences Nutrition. 1992; 21: 154-62.

5. Martin RE, Flick GJ. The seafood industry. OSU Librarie-Guin: Osprey Book; 1990.

6. Kim IS. Food and healthy. Suwon: Shin Kwang publishing co.; 2004.

7. Trivedi VR, Satia MC, Deschamps A, Maquet V, Shah RB, Zinzuwadia $\mathrm{PH}$, et al. Single-blind, placebo controlled randomised clinical study of chitosan for body weight reduction. Nutrition Journal [Internet]. 2016 [cited 2016 Oct 5]:1-12. Available from: http://dx.doi.org/10.1186/ s12937-016-0122-8.

8. Lee GI. The quality characteristics of sauce made with shrimp or crab. Korean Journal Society Food Cook Science. 2004; 20: 164-9.
9. Cho EH, Kim KM, Lee YB. Quality evaluation of teriyaki souce processed with shrimp remnants and its physicochemical properties. The Korean Journal Culinary Resource. 2011; 17: 184-96.

10. Seo JS and CHS. Quality characteristics of fish paste with rebon shrimp powder. Korean Journal Food Preservation. 2012; 19: 519-24.

11. Meilgaard MC, Carr TB, Civille GV. Sensory evaluation techniques. Boca Raton-Florida: CRC Press; 2000.

12. Association of Indonesian nutritionist (PERSAGI). Food composition table of Indonesian. Jakarta: Persatuan Ahli Gizi Indonesia; 2009.

13. Departemen Kesehatan Republik Indonesia. Manual book of supplementary food to toddlers and pregnancy. 2012 [cited 2016 Oct 10]. Available from: http://gizi.depkes.go.id/download/Pedoman Gizi/Panduan PMT Balita dan Bumil BOK 4 Jan 2012.pdf

14. Kementerian Kesehatan Republik Indonesia. Regulation No. 75 - 2013: Nutritional Adequacy recommended (RDA) for the nation of Indonesian. Jakarta: Kementerian Kesehatan Republik Indonesia; 2013.

15. Fatty AR. The effect of adding shrimp against biological nutrient and hedonic test results on the ball-balls tempe. Jakarta: Faculty of Public Health, Universitas Indonesia; 2012.

16. Desmelati, Sumarto, Meilin S. Consumer acceptance and quality assessment nugget shrimp (Acetes erythraeus). Journal Agricultural Research. 2013; 8.

17. Djundjung E. Utilization shrimps powder as a source of calcium and phosphorus in the manufacture of biscuit. Jakarta: Pelita Harapan University; 2011.

18. Lee J, Choi H, Kim K, Chun S, Bae I. Physicochemical and sensory properties of appenzeller cheese supplemented with Rebon shrimp powder. Korean Journal Society for Food Science of Animal Resorces. 2015; 35(2): 232-9.

19. Sipayung EN. Flour potential purple sweet potato (Ipomoea Batatas L.), soybean flour and flour shrimp in making of cookies. Technology Department of Fishery, Faculty of Fisheries and Marine Sciences, Riau University. Riau: Universitas Riau-Pekanbaru; 2013.

20. Haryati S, Sya'rani L, Agustini TW. Study flour substitution mackerel, shrimp, crabs in various concentrations on the quality of physico-chemical and organoleptic instant noodles. Journal Pasir Laut. 2006; 2 (1): 37 51. 